\title{
Effect of Organic Acids on Escherichia coli 0157:H7 and Staphylococcus aureus Contaminated Meat
}

\author{
M. Raftari ${ }^{1}$, F. Azizi Jalilian ${ }^{2}$, A.S. Abdulamir ${ }^{3}$, R. Son ${ }^{1}$, Z. Sekawi ${ }^{2}$ and A.B. Fatimah ${ }^{1, *}$ \\ ${ }^{I}$ Faculty of Food Science and Technology, Universiti Putra Malaysia, 43300, Serdang, Selangor, Malaysia \\ ${ }^{2}$ Faculty of Medicine and Health Science, Universiti Putra Malaysia, 43300, Serdang, Selangor, Malaysia \\ ${ }^{3}$ Microbiology research department, Institute of Bioscience, Universiti Putra Malaysia, 43300, Serdang, Selangor, \\ Malaysia
}

\begin{abstract}
Appropriate and safe antibacterial agents able to decontaminate meat surfaces have long been big concern of meat industry. In an attempt to manage beef carcass contamination, spray wash treatments utilizing three concentrations $(1,1.5$ and $2 \%)$ of acetic, lactic, propionic and formic acids were performed to evaluate their efficacy in reducing numbers of Escherichia coli O157:H7 and Staphylococcus aureus on meat tissues. The procured beef pieces of freshly slaughtered animals were decontaminated with hot water and then inoculated with E. coli $\mathrm{O} 157: \mathrm{H} 7$ and S. aureus individually which then were spray washed with organic acids separately. The total plate count of the treated samples showed that the populations of bacteria decreased after being exposed to organic acids. Spray wash of formic acid resulted in the highest reduction of both bacterial species on meat surface. Significantly, higher log reductions were obtained for $S$. aureus than E. coli $\mathrm{O} 157: \mathrm{H} 7$. It was concluded that organic acids are highly effective in decontaminating meat surfaces and organic acids are shown to be safe, simple, efficient, and cheap modality of meat decontamination which can be highly recommended for industrial scales.
\end{abstract}

Keywords: Meat, beef, Escherichia coli, O157:H7, Staphylococcus aureus, acetic acid, lactic acid, propionic acid, formic acid, food safety.

\section{INTRODUCTION}

The contamination of sterile animal muscle used as food is a direct consequence of slaughtering and dressing of animal carcasses. Wide ranges of microorganisms from different sources are transferred onto meat surfaces that are rich in nutrients [1]. Hide, hair, and hooves of the animals are some of the most widespread sources of bacterial contamination of animals' carcass surfaces [2].

Meat can harbour a large number of pathogenic and spoilage microorganisms during primary and further processing. The number of microorganisms on fresh meat surfaces changes during chill storage following a typical microbial growth pattern. Counts of bacteria in meat are in the range $10^{2}-10^{5} \mathrm{cfu} / \mathrm{cm}^{2}$, but only around $10 \%$ are able to initiate growth [3]. The initial lag phase is attributed to microbial adaptation to changing conditions (chill temperatures and surface desiccation). Ensuing logarithmic growth takes place after cells have accommodated to the new environmental setting and adapted their metabolism. When numbers exceed $10^{7}$ cells per $\mathrm{cm}^{2}$, the first spoilage signs are detected, as off-odours. Another typical spoilage sign, bacterial slime, is noticeable with cell density around $10^{8}$ cells per $\mathrm{cm}^{2}$ [4].

*Address correspondence to this author at the Food Science Department, Faculty of Food Science and Technology, Universiti Putra Malaysia, 43400 Serdang, Selangor, Malaysia; Tel: 00-60-(0)3-89468375; Fax: 00-60-(0)389423552; E-mail: fatimah_upm_fst@yahoo.com
Escherichia coli $\mathrm{O} 157: \mathrm{H} 7$ and Staphylococcus aureus are some of the most frequent pathogens that contaminate meat. E. coli $\mathrm{O} 157: \mathrm{H} 7$ contaminate meat by contact with sewage, or contaminated skin and equipment during slaughtering. $S$. aureus can also be transferred to the surface of carcass from various sources such as skin of cattle, hide, equipment and infected personnel [5].

The involvement of $E$. coli $\mathrm{O} 157: \mathrm{H} 7$ foodborne illnesses and $S$. aureus food poisoning outbreaks has been associated with the consumption of meat and meat products, especially undercooked ground beef [5]. Meat pathogens can cause self-limiting human enteric diseases or systemic and fatal infections of the immunocompromised, the elderly, and the young [1].

E. coli $\mathrm{O} 157: \mathrm{H} 7$ is a Gram negative, facultative anaerobe, non-sporeforming rod shape bacterium. Diseases caused by $E$. coli $\mathrm{O} 157: \mathrm{H} 7$ vary from non-bloody diarrhea and bloody diarrhea through haemorrhagic colitis [6]. S. aureus is a facultative anaerobe, non-motile, spherical, Grampositive bacterium. Nausea, vomiting, retching, abdominal cramping, and prostration are the most common symptoms of $S$. aureus food poisoning [7].

With respect to health and economic problems caused by these bacteria, it is very important to reduce the initial microbial population on meat. Various intervention strategies have been developed to reduce the level of bacteria on 
surface of animals' carcass such as washing and sanitizing with hot water, chlorinated water, food grade acids and salts $[8,9]$.

Organic acids are generally recognized as safe (GRAS) antimicrobial agents, and the dilute solutions of organic acids $(1-3 \%)$ are generally without effect on desirable sensory properties of meat when used as a carcass decontaminant $[9,10]$.

Previous studies focused on limited treatments for controlling bacteria in which results were inconsistent because of the extensive variations in conditions of experiments. Therefore, this study attempted to compare the antibacterial effect of large number of different treatments, three concentrations of four most frequently used organic acids in previous studies as acetic, lactic, propionic and formic acids, on some important species of bacteria on meat. The objective of this research was to study and compare the antibacterial effect of the studied acids at three concentrations (1, 1.5 and $2 \%$ ) on the inoculated bacteria, E. coli $\mathrm{O} 157: \mathrm{H} 7$ and S. aureus, on meat at $4 \pm 1^{\circ} \mathrm{C}$.

\section{MATERIALS AND METHODOLOGY}

\section{Organic Acids}

Three concentrations $(1,1.5$ and $2 \%)$ of four types of food grade organic acids namely Acetic Acid (100\%) (AA), L-Lactic Acid (90\%) (LA), Propionic Acid (99\%) (PA) and Formic Acid (90\%) (FA) (Merck, Germany) were prepared by diluting of glacial form of the acids in sterile distilled water (DW).

\section{Meat Preparation}

Fresh meat was obtained from a local butchery in Serdang, Selangor, Malaysia. Having been packed in sterile bags, the meat was transported to laboratory in a cool box. The samples were prepared immediately after transferring meat to laboratory. Several 10 -gram pieces of meats were procured from freshly slaughtered cow.

\section{Bacterial Strains}

Escherichia coli O157:H7 ATCC 888402 and Staphylococcus aureus ATCC 29247 were obtained from the American Type Culture Collection (ATCC).

\section{SAMPLE PREPARATION}

Each species of bacteria was cultured on standard plate count agar (Merck, Germany) and was then incubated for 24 hours at $37^{\circ} \mathrm{C}$. After 24 hours of incubation, a number of colonies were inoculated in sterile DW, and the cell concentration was adjusted to about $10^{3}$ bacteria/ml.

The prepared 10-gram pieces of meat were decontaminated by washing with hot sterile $\mathrm{DW}\left(80^{\circ} \mathrm{C}\right)$ for 30 seconds, then they were kept for few minutes to reach room temperature. At this stage, about $10^{3}$ bacteria/ml of E. coli $\mathrm{O} 157: \mathrm{H} 7$ and $S$. aureus were inoculated individually on decontaminated meat by pouring and swabbing over the meats surfaces. Subsequently, the inoculated meats with selected bacteria were kept for 20 minutes to allow attachment and absorption of bacteria however; some of the inoculated meats were kept as an inoculation control.

After 20 minutes, the inoculated meat was spray washed with organic acids for 15 seconds individually. Once the inoculated meat was spray washed and drained, they were packed in sterile bags that were stored at $4 \pm 1^{\circ} \mathrm{C}$. Another set was also prepared at the same time as a replicate.

Microbiological analyses were carried out immediately after spray washing until the $12^{\text {th }}$ day of refrigeration. The surface $\mathrm{pH}$ of samples was measured by using flat probe $\mathrm{pH}$ meter (Prescisa, Switzerland) on $0,2^{\text {nd }}, 6^{\text {th }}$ and $12^{\text {th }}$ days of storage. At this step, each piece of meat $(10 \mathrm{~g})$ was aseptically blended with $90 \mathrm{ml}$ of sterile peptone water (Merck, Germany) in a laboratory blender. After that, $1 \mathrm{ml}$ of the blended sample of each inoculated meat with E. coli O157:H7 and S. aureus was transferred onto Petri dishes for pour plate culturing with standard plate count agar (Merck, Germany) individually. Again, another one $\mathrm{ml}$ of the same suspension was cultured as a duplicate. The Petri dishes were then incubated for 24 hours at $37^{\circ} \mathrm{C}$. After 24 hours of incubation, the number of colonies was enumerated in each Petri dish.

\section{Statistical Analysis}

The bacterial population ( $\left.\mathrm{CFU} \mathrm{gr}^{-1}\right)$ was obtained from four replications performed on separate days and their means were converted to $\log _{10} \mathrm{CFU} \mathrm{gr}^{-1}$. Differences between $\log _{10}$ CFU $\mathrm{gr}^{-1}$ of untreated beef carcass tissue and $\log _{10} \mathrm{CFU} \mathrm{\textrm {gr } ^ { - 1 }}$ of treated beef carcass tissue were calculated as log reduction $[11,12]$. Log reductions of treatments were compared by Analysis of variance (ANOVA) test using the general linear models of SPSS 12.0 for windows, $\mathrm{P}$ value $<0.05$ was considered as significant.

\section{RESULTS}

The total plate count of treated samples showed that all treatments had lethal effect on both pathogenic bacteria. The initial surface $\mathrm{pH}$ of meat decreased directly after spray washing with treatments. With progress of storage, it increased (Table $\mathbf{1}$ and 2, Figs. 1 and 2) while the $\mathrm{pH}$ of untreated meat decreased. The population of E. coli O157:H7 (Figs. 3 A-D) and S. aureus (Figs. 4 A-D) reduced after being exposed to all treatments. The mean log reductions of E. coli $\mathrm{O} 157: \mathrm{H} 7$ and $S$. aureus showed in Table 1 and 2 respectively.

The reduction of selected bacteria showed that they were sensitive to all treatments but the antibacterial effect of AA, LA, PA and FA were different. Analysis of variance (ANOVA) of E. coli O157:H7 and S. aureus showed that there is no significant difference $(\mathrm{P}<0.05)$ between lethal effect of AA, LA and PA, but there was significant difference between antibacterial effects of FA and other treatments. Interestingly FA showed the best lethal effect on both pathogenic bacteria in this study.

The results showed, in addition on type of acid, the concentration also plays an important role in reducing the number of bacteria. Analysis of variance (ANOVA) for log reduction of E. coli $\mathrm{O} 157: \mathrm{H} 7$ and $S$. aureus showed that 
Table 1. Log Reductions of E. coli O157:H7 and Surface pH Ranges of Meat Spray Washed with Different Concentrations of AA, LA, PA and FA

\begin{tabular}{|c|c|c|c|c|}
\hline Organic Acid & Log Reduction & \multicolumn{3}{|c|}{ Concentrations } \\
\hline Acetic acid & Ph range & $4.86-5.49$ & $4.74-5.41$ & $4.65-5.38$ \\
\hline Lactic acid & Log cfu/gr & $1.08 \pm 0.5$ & $1.22 \pm 0.5$ & $1.35 \pm 0.5$ \\
\hline \multirow[t]{2}{*}{ Propionic acid } & Log cfu/gr & $0.89 \pm 0.5$ & $1.02 \pm 0.5$ & $1.17 \pm 0.5$ \\
\hline & Ph range & $5.14-5.68$ & $5.02-5.63$ & $4.89-5.45$ \\
\hline \multirow[t]{2}{*}{ Formic acid } & Log cfu/gr & $1.41 \pm 0.5$ & $1.58 \pm 0.5$ & $1.84 \pm 0.5$ \\
\hline & Ph range & $4.39-5.18$ & $4.30-5.14$ & $4.23-5.14$ \\
\hline
\end{tabular}

Table 2. Log Reductions of S. aureus and Surface pH Ranges of Meat Spray Washed with Different Concentrations of AA, LA, PA and FA

\begin{tabular}{|c|c|c|c|c|}
\hline \multirow[t]{2}{*}{ Organic Acid } & \multirow[t]{2}{*}{ Log Reduction } & \multicolumn{3}{|c|}{ Concentrations } \\
\hline & & $1 \%$ & $1.5 \%$ & $2 \%$ \\
\hline \multirow[t]{2}{*}{ Acetic acid } & $\log$ cfu/gr & $1.21 \pm 0.5$ & $1.39 \pm 0.5$ & $1.58 \pm 0.5$ \\
\hline & Ph range & $4.75-5.60$ & $4.64-5.53$ & 4.49-5.46 \\
\hline \multirow[t]{2}{*}{ Lactic acid } & $\log$ cfu/gr & $1.34 \pm 0.5$ & $1.48 \pm 0.5$ & $1.69 \pm 0.5$ \\
\hline & Ph range & $4.58-5.45$ & $4.49-5.43$ & $4.40-5.38$ \\
\hline \multirow[t]{2}{*}{ Propionic acid } & Log cfu/gr & $1.15 \pm 0.5$ & $1.31 \pm 0.5$ & $1.45 \pm 0.5$ \\
\hline & Ph range & $4.99-5.79$ & $4.89-5.73$ & $4.77-5.69$ \\
\hline \multirow[t]{2}{*}{ Formic acid } & Log cfu/gr & $3.16 \pm 0.5$ & $3.16 \pm 0.5$ & $3.16 \pm 0.5$ \\
\hline & Ph range & $4.30-5.46$ & $4.18-5.33$ & $4.09-5.24$ \\
\hline
\end{tabular}
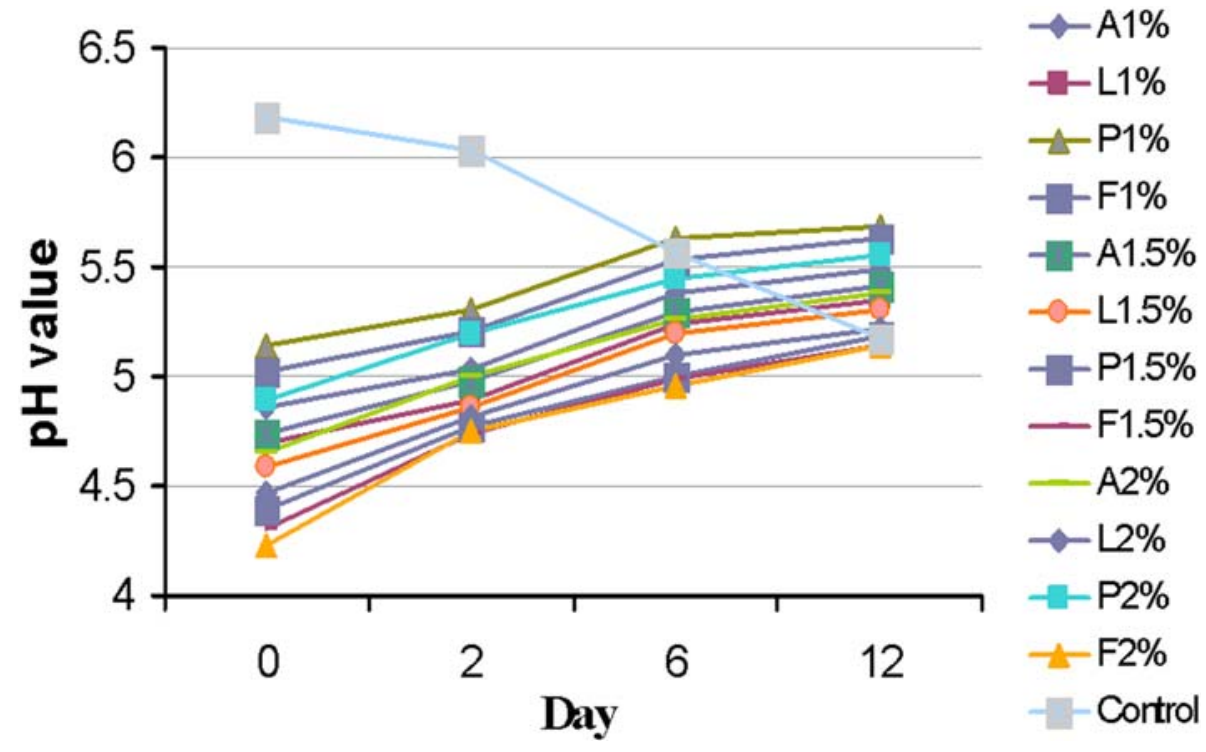

Fig. (1). $\mathrm{pH}$ reduction of $E$. coli $\mathrm{O} 157: \mathrm{H} 7$ on meat spray washed with 3 different concentrations, 1\%, 1.5\%, and 2\% of AA, LA, PA, and FA stored for 12 days. 


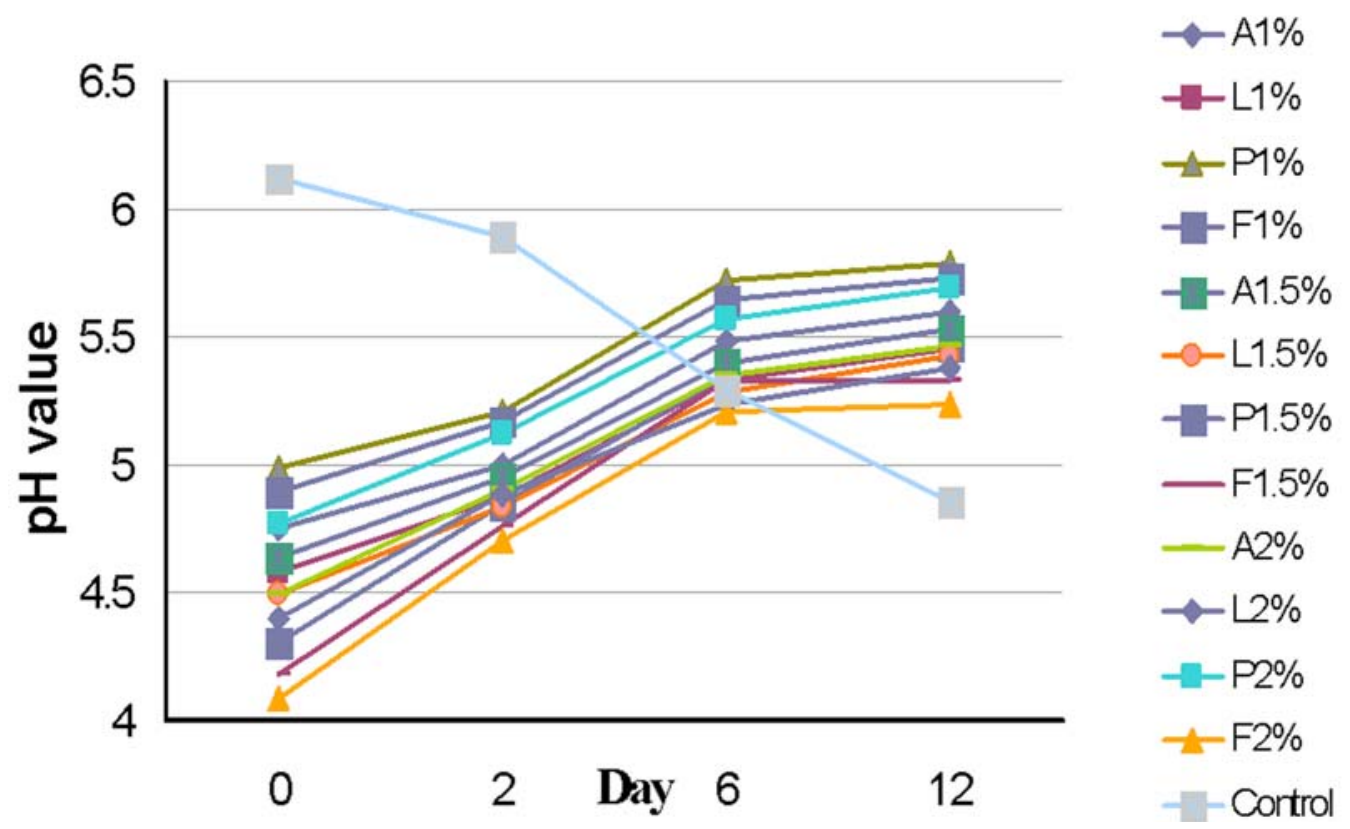

Fig. (2). pH reduction of $S$. aureus on meat spray washed with 3 different concentrations, $1 \%, 1.5 \%$, and $2 \%$ of AA, LA, PA, and FA stored for 12 days.
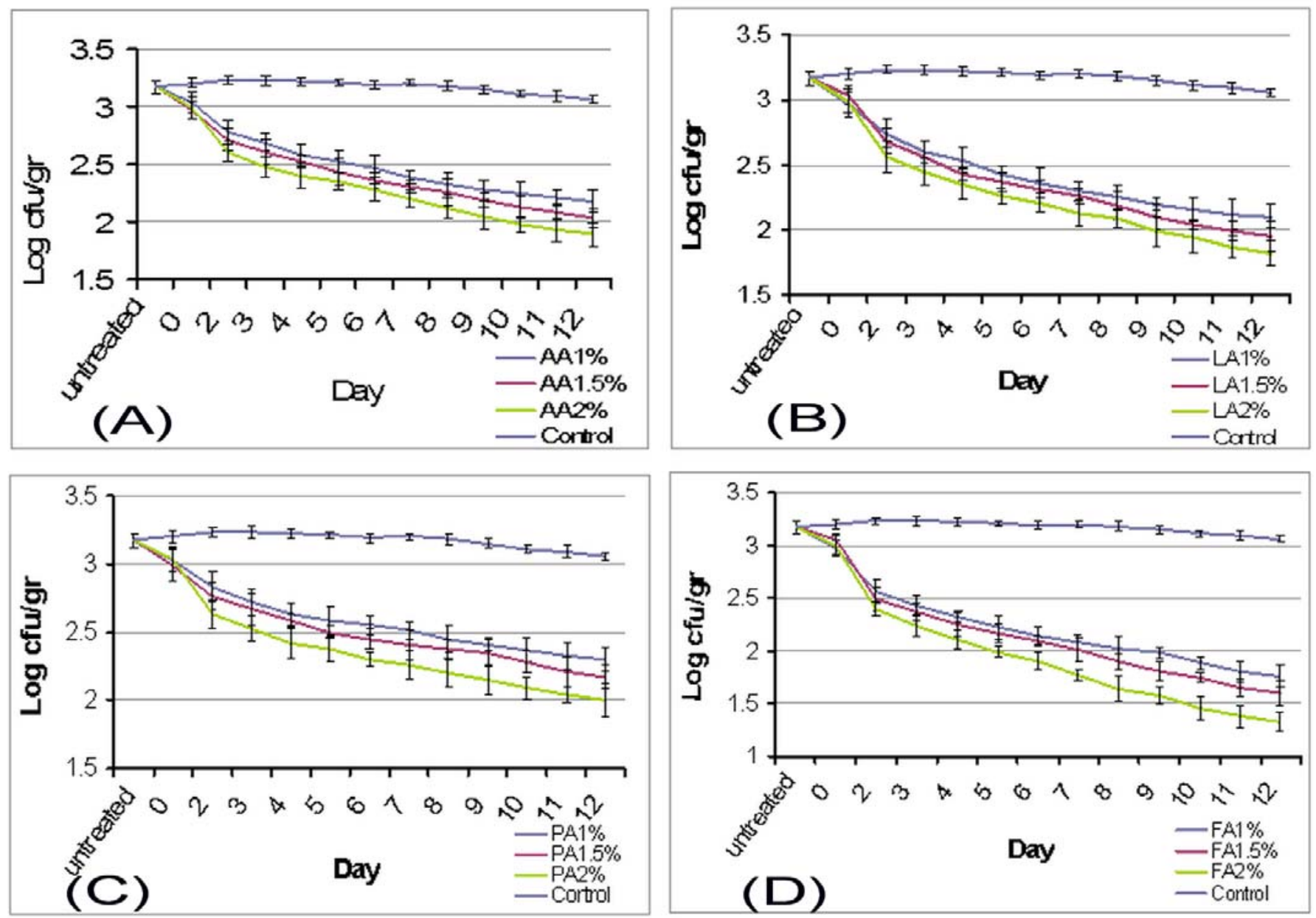

Fig. (3). Cell number reduction of E. coli O157:H7 on meat spray washed with AA (1-A), LA (1-B), PA (1-C), FA (1-D) stored for 12 days. A progressive lowering of $E$. coli $\mathrm{O} 157: \mathrm{H} 7$ number was detected over time in comparison with control. 

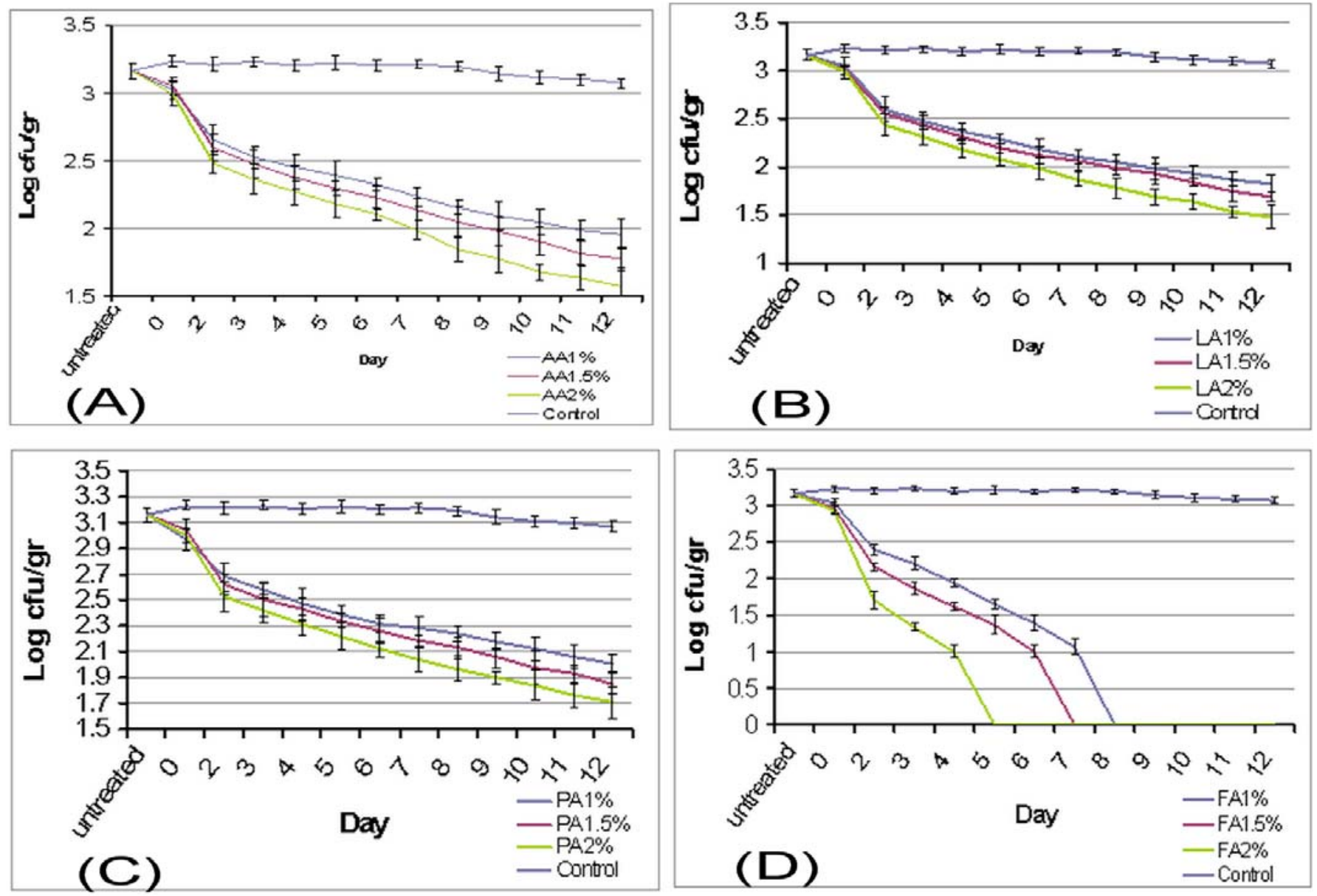

Fig. (4). Cell number reduction of $S$. aureus on meat spray washed with AA (2-A), LA (2-B), PA (2-C), FA (2-D) stored for 12 days. A progressive lowering of $E$. coli $\mathrm{O} 157: \mathrm{H} 7$ number was detected over time in comparison with control.

there was significant difference $(\mathrm{P}<0.05)$ between $1,1.5$ and $2 \%$ concentrations of each organic acid. According to the results the inhibitory effect of $2 \%$ concentration $>1.5 \%$ concentration $>1 \%$ concentration.

The untreated meat showed no significant changes in the populations of E. coli $\mathrm{O} 157: \mathrm{H} 7$ and $S$. aureus at $\mathrm{pH}$ ranges 6.18-5.17 and 6.12-4.86 respectively.

The Mean log reduction of $S$. aureus exposed to FA at concentrations of $1,1.5$ and $2 \%$ was similar to each other but they might be distinguished by three way interaction analysis (acid $\times$ concentration $\times$ day). Three-way interaction analysis showed that these treatments had different log reductions levels on different days. FA at $1,1.5$ and $2 \%$ concentrations reached to $3.16 \log _{10} \mathrm{cfu} / \mathrm{gr}$ on $8^{\text {th }}, 7^{\text {th }}$ and $5^{\text {th }}$ days of storage respectively.

Analysis of variance (ANOVA) of log reductions of both bacteria indicated that there is a significant difference $(\mathrm{P}<0.05)$ between $\log$ reductions of $S$. aureus and that of $E$. coli $\mathrm{O} 157: \mathrm{H7}$. A comparison between the log reductions of E. coli $\mathrm{O} 157: \mathrm{H} 7$ and $S$. aureus after being exposed to various treatments was shown in Fig. (5). The mean log reductions of $S$. aureus and E. coli O157:H7 showed that $S$. aureus was more sensitive to organic acids than E. coli O157:H7.

\section{DISCUSSION}

The main goal of this study was to investigate the antibacterial effect of various organic acids applied as spray wash treatment and explore their effect on decreasing the microbial loads of bacteria efficiently on beef tissue. $\mathrm{PH}$ is one of the important factors, which influences the growth of bacteria. It has been well established that most microorganisms grow best at $\mathrm{pH}$ values around 7.0 [5], therefore, $\mathrm{pH}$ reduction is one of the inhibitor factors, which can limit the growth of bacteria. It was indicated that direct bactericidal action of organic acids results from $\mathrm{pH}$ decrease within bacterial cell and it was also observed that $\mathrm{pH}$ of fish meal decreased directly after acid addition which resulted in reduction of E. coli O157:H7 population [13]. Moreover, another study found that the bacteriostatic effect of propionate against $E$. coli was proportional to $\mathrm{pH}$ decrease in culture medium [14].

To date, organic acids have been found as safe antibacterial agents. Various researchers have proved the antibacterial effect of organic acids on different types of pathogenic bacteria $[11,15,16]$.

In this study, the population of $E$. coli $\mathrm{O} 157: \mathrm{H} 7$ and $S$. aureus decreased after being exposed to all treatments. The reduction rate of the selected bacteria was proportional to 


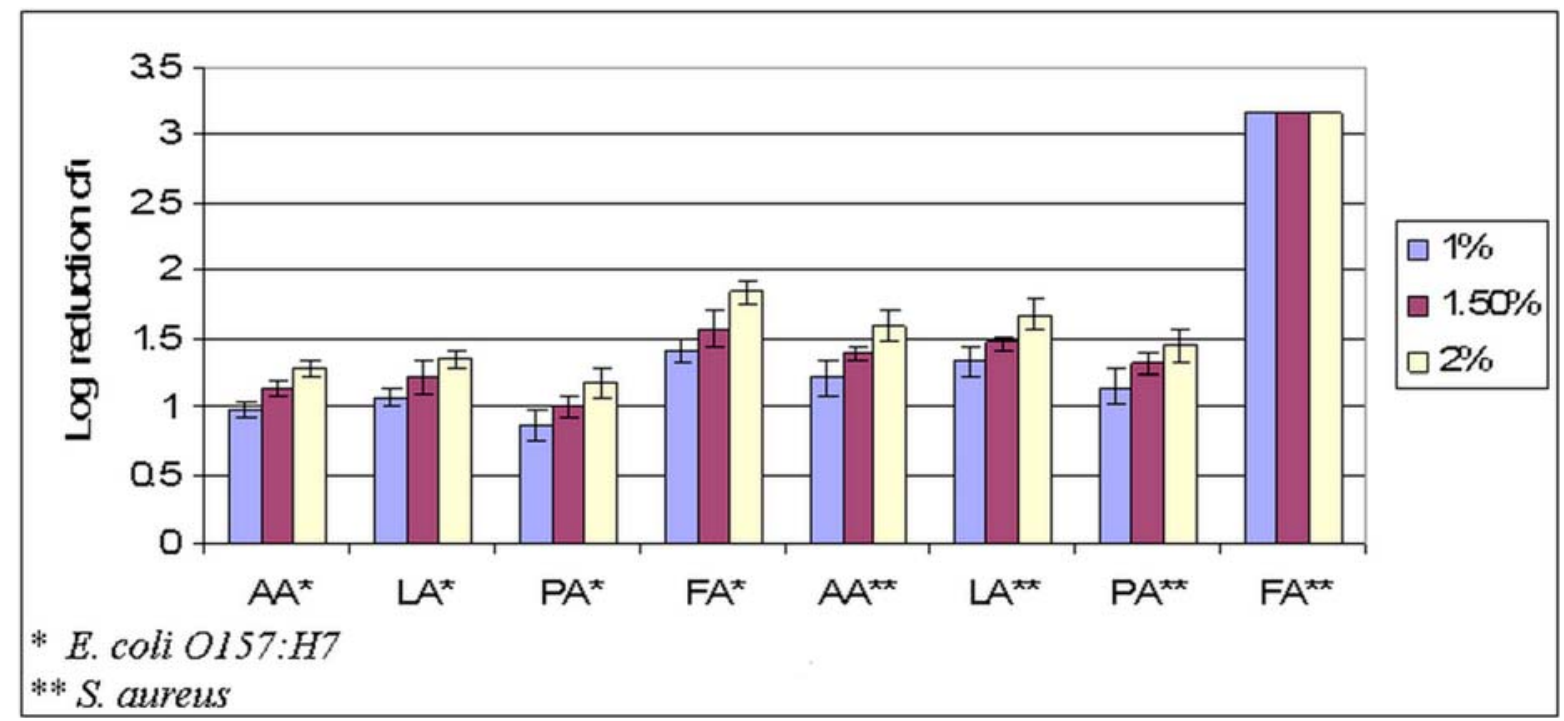

Fig. (5). Log reduction of E. coli $\mathrm{O} 157: \mathrm{H} 7$ and $S$. aureus exposed to AA, LA, PA, and FA and their concentrations.

the type and the concentration of each organic acid. Log reductions analysis showed that increase in the concentration of organic acids resulted in increasing the antibacterial effect of organic acids. These findings are similar to that of another study [17] that scrutinized the reduction in the microbial population of E. coli and S. typhimurium when exposed to 1, 2 and 3\% concentrations of lactic acid. They found that population reduction of E. coli rose by increasing concentration of lactic acid.

The antibacterial effect of the organic acids was found to be caused mainly by the undissociated form of organic acids [18]. Non-dissociated organic acids can passively diffuse through a bacterium's cell wall and once internalized into the neutral $\mathrm{pH}$ of the cell cytoplasm, they dissociate into anions and protons, both of which exert an inhibitory effect on bacteria [19]. Releasing proton ions causes the internal $\mathrm{pH}$ to decrease leading to disruption of proton motive force, and inhibiting substrate transport mechanisms [20,21].

The findings of the current study showed that FA treatment was the most effective in reducing the population of selected bacteria. These results were in agreement with that of another study [22] which indicated that formic acid showed stronger lethal effect on Campylobacter jejuni than propionic and acetic acids. The strong antibacterial effect of formic acid is related to its structure. Formic acid is an organic acid with shortest chain, which could be beneficial for its diffusion into the cell and cause acidification of the cytoplasm [23].

In addition, analysis of $\log$ reductions of E. coli $\mathrm{O} 157: \mathrm{H} 7$ and $S$. aureus showed that the effect of organic acids was more pronounced in S. aureus, which is a Gram-positive bacterium, than in E. coli $\mathrm{O} 157: \mathrm{H} 7$, which is a Gramnegative bacterium. It was reported that the population of Clostridium perfringens decreased more than E. coli and Salmonella sp., in cultures exposed to treatments [23]. The higher sensitivity of gram-positive bacteria to different kinds of antibacterial agents can be related to the structure of the cell wall of this group. Gram-positive bacteria do not possess an outer membrane, hence preservatives can easily enter these cells and their intrinsic resistance is relatively low [24].

\section{CONCLUSION}

Taken together the population of E. coli $\mathrm{O} 157: \mathrm{H} 7$ and $S$. aureus decreased after being exposed to AA, LA, PA and FA treatments. Among the treatments, FA showed the best antibacterial effect on both bacteria. In addition, these results indicated that $S$. aureus was more sensitive to organic acids than E. coli O157:H7. Collectively, formic acid treatment is a feasible and economical method of decontaminating meat.

\section{REFERENCES}

[1] Marshall DL, Bal'a MFA. Microbiology of Meat. In: Hui YH, Ed. Meat Science and Applications. New York: Marcel Dekker, Inc. 2001; pp. 160-181.

[2] Mies PD, Acuff GR, Savell JW, Lucia LM, Covington BR, Harris KB. Decontamination of cattle hides prior to slaughter using washes with and without antimicrobial agents. J Food Prot 2004; 67: 579-82.

[3] Nychas GJ, Dillon VM, Board RG. Glucose, the key substrate in the microbiological changes occurring in meat and certain meat products. Biotechnol Appl Biochem 1988; 10: 203-31.

[4] Gill CO. Microbial Interaction with Meats. In: Brown MH, Ed. Meat Microbiology. London: Applied Science1982; pp. 225-264.

[5] Jay JM, Loessner MJ, Golden DA. Modern food microbiology. $7^{\text {th }}$ ed. New York: Springer Science and Business Media 2005.

[6] Adams MR, Moss MO. Food Microbiology. $2^{\text {nd }}$ ed. Cambridge: The Royal Society of Chemistry 2000.

[7] Seo KS, Bohach GA. Staphylococcus aureus. In: Doyle M, Beuchat L, Eds. Food Microbiology Fundamentals and Frontiers. Washington, DC: ASM Press 2007; pp. 493-519.

[8] Dubal ZB, Paturkar AM, Wasker VS, et al. Effect of food grade organic acids on inoculated $S$. aureus, L. monocytogenes, E. coli and $S$. typhimurium in sheep/goat meat stored at refrigeration temperature. Meat Sci 2004; 66: 817-21.

[9] Smulders FJ, Greer GG. Integrating microbial decontamination with organic acid in HACCP programmes from muscle foods: prospects and controversies. Int J Food Microbiol 1998; 443: 14969.

[10] Kotula KL, Thelappurate R. Microbiological and sensory attributes of retail cuts of beef treated with acetic and lactic acid solution. J Food Prot 1994; 57: 665-70. 
[11] Bell KY, Cutter CN, Sumner SS. Reduction of foodborne microorganisms on beef carcass tissue using acetic acid, sodium bicarbonate, and hydrogen peroxide spray washes. J Food Microbiol 1997; 14: 439-48.

[12] Bjornsdottir K, Breidt FJR, Mcfeeters RF. Protective effects of organic acids on survival of Escherichia coli O157:H7 in acidic environments. Appl Environ Microbiol 2006; 72: 660-64.

[13] Malicki A, Zawadzki W, Bruzewicz S, Graczyk S, Czerski A. Effect of formic and propionic acid mixture on Escherichia coli in fish meal stored at $12^{\circ} \mathrm{C}$. Pak J Nutur 2004; 3: 353-56.

[14] Shin R, Suzuki M, Morishita Y. Influence of intestinal anaerobes and organic acids on the growth of enterohaemorrhagic Escherichia coli O157:H7. J Med Microbiol 2002; 51: 201-06.

[15] Castillo A, Lucia LM, Roberson DB, Stevenson TH, Mercado I, Acuff GR. Lactic acid sprays reduce bacterial pathogens on cold beef carcass surfaces and in subsequently produced ground beef. $\mathrm{J}$ Food Prot 2001; 64: 58-62.

[16] Samelis J, Sofos JN, Kain ML, Scanga JA, Belk KE, Smith GC. Organic acids and their salts as dipping solutions to control Listeria monocytogenes inoculated following processing of sliced pork bologna stored at 4 degrees $\mathrm{C}$ in vacuum packages. J Food Prot 2001; 64: 1722-29.

[17] Anderson ME, Marshall RT. Reducing microbial populations on beef tissues: concentration and temperature of lactic acid. J Food Safety 1990; 10: 181-90.
[18] Dibner JJ, Buttin P. Use of organic acids as a model to study the impact of gut microflora on nutrition and metabolism. J Appl Poult Res 2002; 11: 453-63.

[19] Ricke SC. Perspectives on the use of organic acids and short chain fatty acids as antimicrobials. Poult Sci 2003; 82: 632-39.

[20] Russel JB. Resistance of Streptococcus bovis to acetic acid at low $\mathrm{pH}$ : relationship between intracellular $\mathrm{pH}$ and anion accumulation. Appl Environ Microbiol 1991; 57: 255-59.

[21] Cherrington CA, Hinton M, Chopra I. Effect of short-chain organic acids on macromolecular synthesis in Escherichia coli. J Appl Bacteriol 1990; 68: 69-74.

[22] Chaveerach P, Keuzenkamp DA, Urlings HA, Limpan LJ, Van Knapen F. In vitro study on the effect of organic acids on Campylobacter jejuni/coli populations in mixtures of water and feed. Poult Sci 2002; 81: 621-28.

[23] Skrivanova E, Marounek M, Benda V, Brezina P. Susceptibility of Escherichia coli, Salmonella sp. and Clostridium perfringens to organic acids and monolaurin. Vet Med 2006; 51: 81-8.

[24] Lambert PA. The Bacterial Surface and Drug Resistance. In: Easmon CSF, Ed. Role of the Envelope in the Survival of Bacteria in Infection Medical Microbiology. New York: Academic Press 1983; pp. 1-29.

(C) Raftari et al.; Licensee Bentham Open.

This is an open access article licensed under the terms of the Creative Commons Attribution Non-Commercial License (http://creativecommons.org/licenses/bync/3.0/) which permits unrestricted, non-commercial use, distribution and reproduction in any medium, provided the work is properly cited. 